\title{
CYBER CRIME DAN POTENSI MUNCULNYA VIKTIMISASI PEREMPUAN DI ERA TEKNOLOGI INDUSTRI 4.0
}

\author{
Neri Widya Ramailis, M.Krim
}

\begin{abstract}
The phenomenon of the industrial revolution 4.0 has had many influences, both positive and negative for society. It is undeniable that slowly everything has turned to digital. So that the interaction between humans and technology is inevitable. Such developments make digitization even more difficult to recognize, because everything is now integrated, everything now requires the internet. The opportunities for cyber criminals are getting wider, various kinds of cyber threats continue to emerge and this is a challenge for users. So many crimes that occur today in cyberspace or what is known as cyber crime, especially affect women. There are cases of illegal content (illegal content), violations of privacy (infringement of privacy), threats of private photo or video distribution (malicious distribution), online defamation, to online recruitment (online recruitment). The high number of online-based gender violence, especially for women, seems to open our eyes to always wisely use internet technology in carrying out activities and routines of daily life.
\end{abstract}

Keywords: Cyber Crime, Victimization Criminal, Women, Industrial Revolution 4.0.

Pendahuluan

Ketika berbicara tentang

Revolusi Industri 4.0, istilah ini sudah tidak asing lagi bagi masyarakat. Di Indonesia sendiri, perkembangan teknologi dan informasi terjadi begitu cepat. Dampak era revolusi industri 4.0 tentu sengat besar bagi dunia industri juga perilaku di masyarakat. Dalam bidang industri, yang sebelumnya masih mengandalkan tenaga manusia dalam proses produksi barang. Namun saat ini barang dibuat secara masal dengan menggunakan mesin dan berteknologi canggih. Keadaan seperti ini dikenal sebagai revolusi industri 4.0 .

Fenomena revolusi industri 4.0 ini membawa banyak pengaruh, baik positif maupun negatif bagi 
masyarakat. Dimana semua lini tengah berlomba untuk melakukan digitalisasi agar tidak terlindas oleh teknologi yang terus berkembang. Seperti yang kita ketahui, hampir setiap aspek dalam kehidupan manusia telah terdigitalisasi. Bukan hanya handphone atau komputer saja, melainkan peralatan yang manusia gunakan dalam kehidupan seharihari juga mampu terintegrasi dengan internet. Perkembangan seperti itu membuat digitalisasi rasanya semakin sulit untuk dikenali, karena semua benda kini terintegrasi, semua hal kini membutuhkan internet. Kesempatan para penjahat siber pun semakin luas, berbagai macam ancaman siber terus bermunculan dan hal inilah yang menjadi challenge tersendiri bagi para pengguna.

$$
\text { Istilah Cyber crime, }
$$
belakangan ini kerap terdengar seiring dengan perkembangan dunia digital. Cyber crime atau kejahatan di dunia maya sendiri merupakan salah satu dampak negatif penggunaan media internet sebagai platform yang saat ini banyak digunakan oleh individu masyarakat. Berikut merupakan ulasan singkat mengenai pengertian Cyber crime dan jenis - jenis kejahatan cyber crime yang banyak ditemukan.

$$
\text { Menurut Organization of }
$$

European Community Development (OECD) cyber crime adalah semua bentuk akses ilegal terhadap suatu transmisi data. Artinya, semua bentuk kegiatan yang tidak sah dalam suatu sistem komputer termasuk dalam suatu tindak kejahatan. Secara umum, pengertian cyber crime sendiri memang biasa diartikan sebagai tindak kejahatan di ranah dunia maya yang memanfaatkan teknologi komputer dan jaringan internet sebagai sasaran. Tindakan cyber crime ini muncul seiring dengan kian gencarnya teknologi digital, komunikasi dan informasi yang semakin berkembang. (https://qwords.com/ blog/pengertiancyber-crime)

Setelah mengetahui tentang pengertian cyber crime selanjutnya ini merupakan jenis-jenis cyber crime yang banyak terjadi di dunia. Pertama, Pencurian Data. Aktivitas cyber crime yang satu ini biasanya dilakukan untuk memenuhi kepentingan komersil 
karena ada pihak lain yang menginginkan data rahasia pihak lain. Tindakan ini tentu bersifat ilegal masuk ke dalam aktifitas kriminal karena bisa menimbulkan kerugian materil yang berujung pada kebangkrutan suatu lembaga atau perusahaan.

Kedua, Cyber Terorism. Ini merupakan tindakan cyber crime yang sedang banyak diperangi oleh negaranegara besar di dunia, termasuk Indonesia. Pasalnya, aktivitas cyber terorism kerap kali mengancam keselamatan warga negara atau bahkan stake holder yang mengatu jalannya pemerintahan. Ketiga, Hacking. Tindakan berbahaya yang kerap kali dilakukan oleh para programer profesional ini biasanya secara khusus mengincar kelemahan atau celah dari sistem keamanan untuk mendapatkan keuntungan berupa materi atau kepuasan pribadi Misalnya, seorang hacker yang diberi tugas untuk melacak keberadaan seorang buronan atau hacker yang bekerjasama dengan pihak bewenang untuk memberantas aktivitas ilegal di ranah digital.
Ke Empat, Carding adalah istilah yang digunakan untuk menyebut penyalahgunaan informasi kartu kredit milik orang lain. Para carder (pelaku carding) biasanya menggunakan akses cartu credit orang lain untuk membeli barang belanjaan secara online. Kemudian, barang igratisan tersebut dijual kembali dengan harga murah untuk mendapatkan uang.

Ke Lima, Defacing bisa dibilang menjadi aktivitas kejahatan online yang paling ringan. Hal tersebut salah satunya karena para pelaku deface biasanya menyasar websitewebsite non-profit seperti situs pemerintahan, sekolah, atau universitas. Ke Enam, Istilah cybersquatting mungkin belum begitu familiar di kalangan pengguna di Tanah Air. Wajar memang pasalnya tindakan penyerobotan domain sendiri memang memerlukan modal serta kejelian yang tidak dimiliki banyak orang. Hasil cyber crime ini biasanya berupa uang tebusan yang nilainya tidak wajar.

Ke Tujuh, Hampir mirip dengan cybersquatting, tindakan cyber 
typosquatting sama-sama mengincar domain milik perusahaan terkenal untuk dijadikan sasaran. Bedanya, aktivitas ini memanfaatkan kemiripan domain serta kelalaian pengguna yang jarang memeriksa ulang URL website perusahaan. Salah satu tujuan dari cyber typosquatting adalah untuk menjatuhkan citra baik dari brand bersangkutan dengan melakukan tindakan penipuan atau hal-hal ilegal lain yang melanggar undang-undang.

Ke Delapan, Menyebarkan konten ilegal yang melanggar undangundang menjadi kasus cyber crime paling banyak diperhatikan. Pasalnya, aktivitas ini biasanya melibatkan tokoh terkenal atau konten yang mampu memancing kontroversi. Beberapa contoh konten llegal yang masuk dalam ranah cyber crime di antaranya adalah video porno, penjualan senjata api ilegal, jual beli narkotika, dan lain sebagainya.

Berikut ini merupakan contoh kasus cyber crime yang terjadi di Indonesia maupun di dunia. Pertama, memalsukan akun facebook seseorang. Salah satu contoh kejahatan cyber crime yang paling sering terjadi adalah pengkloningan akun facebook milik seseorang. Tindakan ini marak terjadi kepada para publik figur atau tokoh terkenal yang memiliki banyak pengikut. Dengan banyaknya atensi yang diterima oleh akun kloningan, pemalsu biasanya akan semakin cepat mendapat korban. Cyber crime model ini biasanya meminta bayaran uang dengan cara transfer ke rekening tertentu. Jadi, jangan mudah percaya jika Anda dihubungi seseorang yang mengaku sedang membutuhkan bantuan. Kedua, Fenomena Ransomware WannaCry. Beberapa tahun lalu jagat digital sempat diramaikan dengan kemunculan virus komputer Ransomware WannaCry yang mampu mengunci data komputer seseorang. Untuk bisa membuka dan mengakses data tersebut syarat yang harus anda lakukan adalah membawa sejumlah uang tebusan melalui wallet Bitcoin.

Begitu banyak kejahatan yang terjadi saat sekarang ini di dunia maya atau yang dikenal dengan cyber crime, terutama menimpa kaum perempuan. Ada kasus konten ilegal (illegal content), pelanggaran privasi 
(infringement of privacy), ancaman distribusi foto atau video pribadi (malicious distribution), pencemaran nama baik (online defamation), hingga rekrutmen online (online recruitmen).

Berdasarkan data yang dikutip dari laman web CNN Indonesia, Rabu, 30/01/2019 03:31 WIB. Kepala Divisi Online Safety SAFEnet Boaz Simanjuntak menjelaskan,terjadinya lonjakan kekerasan berbasis gender yang dilakukan secara online (KBGO). Ia menuntut kepada pemerintah dan DPR untuk segera mengesahkan Rancangan Undang-Undang Penghapusan Kekerasan Seksual (RUU PKS). Selain itu ia juga mendorong pemerintah menjamin perlindungan korban KBGO dan meminta aparat penegak hukum untuk memperhatikan kasus KBGO secara kontekstual, menindak tegas pelaku, dan tidak membuat korban sebenarnya menjadi korban dua kali dalam proses penegakan keadilan. Kata Boaz, pemerintah dan DPR harus segera merumuskan KBGO sebagai pasal yang diatur dalam Rancangan UndangUndang Penghapusan Kekerasan Seksual (RUU PKS) serta meminta masyarakat untuk menghormati hakhak digital sesama pengguna internet termasuk hak atas rasa aman bagi perempuan dan kaum rentan. (https://www.cnnindonesia.com/teknol ogi/maraknya-kekerasan-terhadapperempuan-di-dunia-maya).

Di lain hal, sesuai isi pemberitaan dari laman web JawaPos.com Direktur Eksekutif Women`s Crisis Centre (WCC) Palembang Yeni Roslaini mengatakan sepanjang 2020 perempuan korban tindak kekerasan di dunia maya atau cyber crime di Pelembang mengalami peningkatan. Ia menjelaskan berdasarkan data pada 2019 WCC hanya menerima delapan pengaduan kekerasan berbasis gender daring/online (KBGO) sedangkan pada 2020 menjadi 28 kasus. Kekerasan cyber crime yang dilaporkan para korban tersebut sebagian besar berupa penyebaran foto dan video pribadi secara daring di media sosial oleh teman dekat laki-laki dan mantan pacar atau suaminya. "Tindak kekerasan terhadap perempuan berbasis gender daring/online itu mengalami 
peningkatan pada masa pandemi Covid-19”, ujar Yeni. Selanjutnya pada 2021, WCC menyiapkan berbagai kegiatan yang dapat meminimalkan kasus tindak kekerasan terhadap perempuan. Untuk mencegah terus meningkatnya jumlah perempuan yang menjadi korban tindak kekerasan di dunia maya atau cyber crime, pihaknya mengingatkan kepada para perempuan terutama anak-anak remaja putri untuk hati-hati memuat/menyebarkan foto atau video pribadi di media sosial. Selain itu, bisa diproses hukum sesuai dengan Undang Undang Informasi dan Transaksi Elektronik (ITE). Dampak dari tindakan kekerasan dunia maya itu tidak saja terhadap fisik dan psikis, tapi juga terhadap keberlangsungan kehidupan korban dan keluarganya. Oleh karena itu, perempuan harus bijak dalam menggunakan media sosial.

(https://www.jawapos.com/today/02/01 /2021/Jumlah Perempuan Korban Kekerasan Dunia Maya di Palembang Meningkat).

Kemudian, sepanjang 2017, Komnas Perempuan juga mencatat adanya 65 kasus kekerasan terhadap perempuan di dunia maya. Pelakunya mulai dari pacar, mantan pacar, dan suami, selain juga kolega, sopir transportasi online dan pelaku anonim, bahkan sampai warga negara asing, sehingga mereka menyebutnya kejahatan transnasional yang membutuhkan perhatian khusus pemerintah. Secara khusus Komnas Perempuan juga mencatat bahwa "kejahatan cyber dengan korban perempuan seringkali berhubungan dengan tubuh perempuan yang dijadikan objek pornografi. Salah satu bentuk kejahatan cyber yang paling sering dilaporkan adalah penyebaran foto atau video pribadi di media sosial dan atau website pornografi. Kasus ini biasanya menghebohkan publik sehingga menambah beban psikis bagi korban, kata Mariana Amiruddin. Bentuk kejahatan cyber lain yang juga sering dilaporkan adalah munculnya ancaman pada korban bahwa foto atau video pribadinya akan disebar, dan ini biasanya dilakukan agar korban tidak melapor atau meninggalkan pelaku dalam hubungan berpacaran. Selain itu, kejahatan ini juga meliputi pengiriman teks yang berisi kata-kata 
sampai foto alat kelamin pelaku yang bertujuan untuk menyakiti, menakuti, mengancam, dan mengganggu korban. (https://www.bbc.com//indonesia/trens osial).

$$
\text { Hampir sama dengan }
$$
pernyataan isi berita sebelumnya, Komisioner Komnas Perempuan Riri Khariroh mengatakan kasus kekerasan berbasis gender online (KBGO) di Indonesia meningkat setiap tahun. Terakhir, pada 2018 Komnas HAM mencatat ada 95 kasus dari sebelumnya hanya lima kasus pada 2016. Adapun bentuk-bentuk kekerasan di dunia maya antara lain pelecehan online, sexting, perdagangan manusia dan online rekrutmen. Ia meyakini jumlah kasus tersebut lebih kecil dibandingkan dengan jumlah kasus sebenarnya di masyarakat. Sebab, sebagian besar perempuan yang menjadi korban di ranah online tidak tahu harus melapor kemana. Dari kasus-kasus itu, yang paling banyak yaitu sekitar 61 persen dari kasus yang ada terkait dengan ancaman dari pelaku untuk menyebarkan video dan foto pribadi. Riri menambahkan, pelaku kekerasan berupa penyebaran data pribadi perempuan sebagian besar merupakan pasangannya yakni pacar atau suami. Salah satu motifnya yaitu ingin menjatuhkan pasangan perempuannya ketika sedang bermasalah. Dari segi umur, rata-rata yang mengadu ke Komnas Perempuan masih sangat muda. Kategori umurnya itu sekitar mulai 20-35 tahun. Banyak sekali yang putus asa dan ingin bunuh diri karena martabatnya di ujung tanduk, tambahnya. Riri Khariroh menjelaskan lembaganya telah berkoordinasi dengan Polri dan Kementerian Komunikasi dan Informatika untuk mengatasi kekerasan berbasis gender online dan penyelewengan data pribadi. Sebab, kata dia, para pelaku kekerasan selama ini kerap tidak mendapatkan sanksi apapun sehingga menyuburkan impunitas kasus kekerasan terhadap perempuan.

(https://www.voaindonesia.com/kekera san-perempuan-di-dunia-maya-setiaptahun-meningkat).

\section{Permasalahan}

Tingginya angka kekerasan gender berbasis online, terutama 
menimpa kaum perempuan seolah membuka mata kita untuk senantiasa bijak menggunakan teknologi internet dalam menjalankan aktifitas dan rutinitas kehidupan sehari-hari. Pola gaya hidup yang cenderung meningkat di era moderenisasi membuat setiap individu masyarakat telah memiliki handphone yang berteknologi canggih, seolah-olah barang ini menjadi suatu hal yang sangat amat wajib untuk di punyai. Selain mudah di dapat, harga yang cukup relatif murah dan mudah di jangkau membuat handphone mampu di miliki oleh setiap kalangan masyarakat.

Kecanggihan teknologi handphone saat ini mampu memunculkan berbagai macam inovasi dan perbedaan dari tahun ke tahun. Fungsi handphone tidak hanya sekedar sebagai alat berkomunikasi untuk dapat saling bertukar informasi saja, baik jarak dekat maupun dalam bentuk komunikasi jarak jauh antara manusia satu dengan yang lainnya. Namun, seiring perkembangan zaman hampir semua jenis handphone dan android kini memiliki fitur dan aplikasi yang cukup lengkap dan selalu terhubung

dengan layanan internet dan sosial media yang dapat terkoneksi sampai ke penjuru dunia sehingga handphone tersebut telah dijadikan alat multi fungsi sebagai bentuk tren fashion dan gaya hidup (life style) yang bisa digunakan untuk mengakses foto, video call, menonton, membaca berita, berjualan, ladang bisnis dan lain sebagainya. Oleh sebab itu kita harus berhati-hati dalam menggunakan layanan internet agar tidak menjadi korban kejahatan di dunia maya.

\section{Kerangka Konseptual}

Konsep Cyber Crime

Pesatnya perkembangan
teknologi komputer dan teknologi
informasi, pelaksanaan kejahatan juga
mengikuti dan memanfaatkan
teknologi komputer dan informasi
tersebut dilihat sebagai bentuk cyber
crime. Menurut Barua dan Dayal
(2001) cyber crime pada dasarnya
adalah kejahatan lama (konvensional)
tetapi mempergunakan teknologi baru.
Sedangkan Podgor (2002) yang
mempergunakan istilah kejahatan
komputer mengatakan bahwa bentuk-
bentuk kejahatan ini sama dengan


kategori tradisional dalam hukum pidana.

Bentuk-bentuk kejahatan yang termasuk kategori cyber crime antara lain. Carding yaitu penyalahgunaan nomor kartu kredit orang lain untuk membeli barang melalui layanan situs internet (web site). Carding ini dapat dikategorikan sebagai pemalsuan atau penipuan menurut hukum pidana (kejahatan lama). Hacking, memasuki situs milik orang lain melalui internet dengan tujuan untuk menunjukkan bahwa teknik pengamanan yang dibuat oleh pemilik situs dapat ditembus. Hacking ini dapat disamakan dengan memasuki wilayah pribadi milik orang lain tanpa izin. Cracking, serupa dengan Hacking, tetapi ketika berhasil masuk ke program yang dimasuki atau bahkan merusaknya. Cracking dapat dikategorikan sebagai perusakan menurut hukum pidana, atau dalam kriminologi disebut juga sebagai vandalisme. Spaming yaitu mengirimkan surat elektronik (e-mail) ke alamat e-mail orang lain yang tidak diperlukan oleh penerima surat. Penerima surat tidak mengenal atau tidak mempunyai hubungan apapun dengan pengirim. Biasanya e-mail yang dikirimkan adalah iklan penawaran barang dan jasa, termasuk pornografi. Spaming ini dalam hukum pidana dapat dikategorikan sebagai perbuatan yang tidak menyenangkan. Apabila e-mail yang dikirim tersebut ditujukan kepada penerima khusus, dan biasanya isi surat berisi kata-kata yang menista penerima surat atau ancaman maka tindakan tersebut disebut sebagai cyber stalking (Mustofa, 2010 : 214).

Selain bentuk kejahatan tersebut di atas, teknologi informasi, melalui layanan internet dapat dimanfaatkan untuk melakukan kejahatan peredaran pornografi, pembajakan hak cipta dan lain sebagainya. Sementara itu akuntansi berbasis teknologi informasi juga dapat disalahgunakan, yang sesungguhnya sama saja dengan penyelewengan akuntansi atau pembukuan secara manual.

Pelaku cyber crime tidak mempunyai ciri yang khas, kecuali berhubungan dengan kemahirannya dalam mempergunakan komputer dengan teknologi informasi. Demikian 
pula korban cyber crime adalah individu dan lembaga (bisnis maupun negara) yang memanfaatkan teknologi informasi.

\section{Konsep Viktimisasi}

Menurut Arif Gosita (1985)

viktimisasi kriminal merupakan proses penimbulan korban suatu perbuatan yang dengan sengaja melawan hukum dapat menimbulkan penderitaan fisik, mental, dan sosial pada seseorang/ sekelompok orang/ lembaga oleh orang/ lembaga baik untuk kepentingan sendiri/ orang lain. Lebih lanjut, R. Elias (1986) tergantung pada kompleksnya faktor yang menentukan seperti pelaku, korban kerusakan/ kerugian dan keadaan/ situasi viktimisasi menunjukkan berapa banyak seseorang menderita sebagai korban (Sihite, 2007 : 200).

Lebih lanjut Mustofa (2010 : 59-61) menjelaskan, untuk memahami pola viktimisasi secara lebih sistematis, beberapa sarjana menyusun tipologi korban kejahatan. Penyusunan tipologi korban ini dapat memperluas wawasan kita karena ada saja orang yang secara berulang menjadi korban kejahatan yang sama, tanpa pernah menjadikan pengalaman viktimisasi tersebut untuk memperbaiki nasib. Misalnya ada orang yang secara berulang menjadi korban pencopetan dan tidak ada usaha atau tidak mampu untuk meningkatkan keamanan diri agar tidak lagi menjadi korban pencopetan lagi. Selain itu ada pula kelompok masyarakat yang menjadi korban kejahatan terus-menerus karena bentuk tindakan yang merugikan mereka terus berlangsung, misalnya korban pencemaran lingkungan yang lingkungan alamnya tidak direhabilitasi, merupakan korban terus menerus (continuing victimization). Tindakan represif penguasa otoriter juga menghasilkan viktimisasi yang terus menerus.

Sejumlah penulis dan peneliti bidang viktimologi merumuskan beberapa tipologi korban kejahatan. Tipologi-tipologi tersebut dirumuskan berdasarkan kriteria yang berbedabeda, namun demikian terdapat persamaan umum dalam maknanya M.E. Wolfgang (1967), merumuskan tipologi korban kejahatan secara bertingkat, meliputi:

1) Primary victimization 
2) Secondary victimization

3) Tertiary victimization

4) Mutual victimization

5) No victimization

Kategori-kategori korban yang dirumuskan oleh Wolfgang secara bertingkat tersebut oleh E.A. Fattah (1967) dirumuskan berdasarkan peran korban, menjadi :

1) Non participating victim

2) Latent or predisposed victims

3) Provocative victims

4) Participating victims

5) False victims

B. Mendelsohn sebagai pelopor viktimologi merumuskan tipologi korban berdasarkan tingkat kesalahan korban dalam peristiwa kejahatan (lihat Schafer, 1968), menjadi :

1) The completely innocent victim.

2) The victim with minor guilt, due to his ignorance.

3) The victim as guilty as the offender.

4) The victim more guilty than the offender.

a. The provoker victim

b. The imprudent victim
5) The most guilty victim, guilty alone.

6) The simulating victim, imaginary victim.

\section{Konsep Perempuan}

Pada konteks kekinian kalimat "perempuan" lebih sering digunakan dari pada kalimat "wanita", hal ini dapat dibuktikan ketika kita mengikuti acara pertemuan ilmiah, ruang seminar dan diskusi yang mana topik atau tema kegiatan berhubungan dengan persoalan gender dan perempuan, bahkan dalam lingkup penelitian ilmiah yang dilakukan oleh lembaga swadaya masyarakat istilah "perempuan" lebih banyak digunakan.

Menurut Rachmat Syafa'at (1998:1) secara historis istilah "wanita" berasal dari leksikon Bahasa sanksekerta, wanita, yaitu "yang di inginkan oleh kaum laki-laki”, sehingga lebih berkonotasi pasif. Dalam perkembangan Bahasa Indonesia, Siusan Kwelja (1991) mengatakan bahwa ungkapanyang ada menyebutkan bahwa wanita adalah pemelihara yang sabar, pasif, diam dan menjadi pesakitan, kurang standar, 
tidak diharap untuk menonjolkan diri dan boleh berprofesi, tetapi kurang diakui perannya. Sedangkan istilah "perempuan" menurut Prasetio Murniati sengaja dipergunakan untuk istilah "women" berasal dari akar Bahasa Melayu yang berarti "empu" induk, artinya "yang memberi hidup". Istilah ini tampaknya lebih dinamis dan syarat makna dibanding dengan istilah "wanita".

Penggunaan istilah tersebut ada yang mengaitkan dengan upaya membangkitkan semangat kaum hawa dan mendekonstruksi praktik-praktik diskriminasi gender, yang dianggap merugikan perempuan. Dengan sebutan "perempuan" ini, ia diharapkan tidak sekedar bisa menikmati kehidupan ini, tetapi sekaligus dapat memberdayakan potensi-potensi dirinya yang berkaitan dengan kepentingan yang bersifat makro (Wahid \& Muhammad, 2011 : 29).

\section{Konsep Teknologi}

Kata teknologi berasal dari bahasa Yunani, techne yang berarti 'keahlian' dan logia yang berarti 'pengetahuan'. Dalam pengertian yang sempit, teknologi mengacu pada obyek benda yang digunakan untuk kemudahan aktivitas manusia, seperti mesin, perkakas, atau perangkat keras (Rusman dkk, 2012 : 78).

Jadi teknologi adalah semacam perpanjangan tangan manusia untuk dapat memanfaatkan alam dan sesuatu yang ada di sekelilingnya secara lebih maksimal. Dengan demikian, secara sederhana teknologi bertujuan untuk mempermudah pemenuhan kebutuhan manusia.

Teknologi Informasi menurut Richard Weiner dalam Websters New Word Dictinonary and Communication disebutkan bahwa Teknologi Informasi adalah pemprosesan, pengolahan, dan penyebaran sata oleh kombinasi komputer dan telekomunikasi (Sa'ud, 2008 : 183).

Teknologi Informasi menurut Hamzah B. Uno dan Nina Lamatenggo adalah suatu teknologi yang digunakan untuk mengolah, memproses, mendapatkan, menyusun, menyimpan, memanipulasi data dalam berbagai cara untuk menghasilkan informasi yang berkualitas, yaitu informasi yang 
relevan, akurat dan tepat waktu (Dimyati dan Mudjiono, 1999 : 157).

Konsep Revolusi Industri 4.0

Menurut Kanselir Jerman, Angela Merkel (2014) berpendapat bahwa Industri 4.0 adalah transformasi komprehensif dari keseluruhan aspek produksi di industri melalui penggabungan teknologi digital dan internet dengan industri konvensional. Schlechtendahl dkk menekankan definisi kepada unsur kecepatan dari ketersediaan informasi, yaitu sebuah lingkungan industri di mana seluruh entitasnya selalu terhubung dan mampu berbagi informasi satu dengan yang lain.

Pengertian yang lebih teknis disampaikan oleh Kagermann dkk (2013) bahwa Industri 4.0 adalah integrasi dari Cyber Physical System (CPS) dan Internet of Things and Services (IoT dan IoS) ke dalam proses industri meliputi manufaktur dan logistik serta proses lainnya. CPS adalah teknologi untuk menggabungkan antara dunia nyata dengan dunia maya. Penggabungan ini dapat terwujud melalui integrasi antara proses fisik dan komputasi (teknologi embedded computers dan jaringan) secara close loop (Lee, 2008). Hermann dkk (2015) menambahkan bahwa Industri 4.0 adalah istilah untuk menyebut sekumpulan teknologi dan organisasi rantai nilai berupa smart factory, CPS, IoT dan IoS. Smart factory adalah pabrik modular dengan teknologi CPS yang memonitor proses fisik produksi kemudian menampilkannya secara virtual dan melakukan desentralisasi pengambilan keputusan. Melalui IoT, CPS mampu saling berkomunikasi dan bekerja sama secara real time termasuk dengan manusia. IoS adalah semua aplikasi layanan yang dapat dimanfaatkan oleh setiap pemangku kepentingan baik secara internal maupun antar organisasi. Terdapat enam prinsip desain Industri 4.0 yaitu interoperability, virtualisasi, desentralisasi, kemampuan real time, berorientasi layanan dan bersifat modular. Berdasar beberapa penjelasan di atas, Industri 4.0 dapat diartikan sebagai era industri di mana seluruh entitas yang ada di dalamnya dapat saling berkomunikasi secara real time 
kapan saja dengan berlandaskan pemanfaatan teknologi internet dan CPS guna mencapai tujuan tercapainya kreasi nilai baru (Prasetyo \& Sutopo, $2018: 19$ ).

\section{Teori Viktimisasi Kriminal}

$$
\text { Mustofa (2010 : 54) }
$$

menjelaskan Teori viktimisasi kriminal utama dihasilkan dalam bidang viktimologi baru muncul pada tahun 1978. Pada tahun itu Hindelang Gottfredson, dan Garofalo merumuskan Lifestyle-Exposure Theories Of Victimization (Teori-teori viktimisasi karena terpaan gaya hidup). Tahun berikutnya (1979), Cohen dan Felson merumuskan Routine Activity Theory (Teori Aktifitas Rutin). Tahun 1993, atau lebih dari satu decade kemudian, Meier dan Miethe mencoba menggabungkan kedua teori diatas menjadi Structural_Choice Model Of Victimization (Model Viktimisasi Pilihan Struktural).

Teori Terpaan Gaya Hidup, yang dirumuskan oleh Hindelang, Gottfredson dan Garafalo, pada mulanya bertujuan untuk mengukur perbedaan antara kelompok sosial dalam resiko menghadapi viktimisasi kejahatan kekerasan, namun kemudian diperluas juga atas resiko menghadapi viktimisasi kejahatan kekerasan, namun kemudian diperluas juga atas resiko viktimisasi kejahatan terhadap harta benda. Perluasan perhatian tersebut kemudian juga dijadikan landasan dalam merumuskan proses ketika pelaku kejahatan melakukan seleksi sasaran.

Asumsi dasar dari Teori Terpaan Gaya Hidup adalah bahwa perbedaan resiko orang dalam menghadapi viktimisasi kejahatan dipengaruhi oleh adanya perbedaan gaya hidup dari orang tersebut. Perbedaan gaya hidup ini penting bagi kemungkinan menghadapi resiko viktimisasi kriminal karena berhubungan dengan perbedaan dari terpaan daerah rawan kejahatan, waktu rawan kejahatan, dan lain-lain ynag merupakan keadaan resiko tinggi mengalami viktimisasi kriminal. Dengan demikian, gaya hidup orang yang diartikan sebagai aktifitas harian rutin vokasional (bekerja, bersekolah, menjaga rumah dan sebagainya), 
aktifitas hiburan, merupakan faktor kritis orang tersebut dalam menanggung resiko viktimisasi kriminal. Aktifitas harian seseorang akan dapat membawa orang tersebut mengalami kontak dengan kejahatan atau meningkatkan resiko viktimisasi kriminal. Orang yang tinggal di dalam rumah pada umumnya mengecil resikonya dari viktimisasi kriminal, sebaliknya orang yang berada ditempat-tempat umum akan meningkat resikonya mengalami viktimisasi kriminal (HGG, 1978 : 241).

Perbedaan gaya hidup ditentukan oleh ciri demografis seseorang yang akan mempengaruhi respond an adaptasi individual terhadap berbagai harapan peran dan desakan structural. Kedudukan seseorang yang berhubungan dengan usia, jenis kelamin, penghasilan, status perkawinan, pendidikan, dan pekerjaan, berhubungan dengan tingkat resikonya dalam mengalami viktimisasi kriminal. Perbedaan kedudukan tersebut mengandung konsekuensi respon dan harapan peran yang berbeda dari masyrakat.
Seseorang laki-laki diharapkan oleh masyarakat sebagai pecari nafkah dan karenanya akan lebih banyak berada diluar rumah. Sementara itu perempuan dalam harapan peran secara tradisional dan dominan adalah mengurus rumah tangga, oleh karenanya akan lebih sering berada di dalam rumah. Perbedaan jenis kelamin dan harapan peran tersebut mempunyai dampak resiko viktimisasi yang berbeda pula. Dengan adanya perubahan sosial, yaitu tuntutan emansipasi perempuan untuk tidak semata-mata berperan di lingkungan domestik (rumah tangga) saja, dan berhak untuk mengembangkan karir, mengubah pola kecenderungan viktimisasi kriminal menurut jenis kelamin, karena jumlah perempuan yang melakukan kegiatan rutin diluar rumah semakin bertambah.

\section{Teori Aktifitas Rutin yang} dikemukakan oleh Cohen dan Felson (1979) mempunyai kemiripan dengan Teori Terpaan Gaya Hidup. Keduanya menekankan pentingnya aktifitas rutin yang berkaitan dengan meningkatnya resiko orang mengalami viktimisasi kriminal, atau meningkatnya 
kesempatan orang berbuat kejahatan.

Perbedaan yang jelas antara kedua teori tersebut adalah bahwa teori aktifitas rutin pada mulanya dikembangkan untuk mengukur tingkat perbedaan resiko viktimisasi menurut dimensi waktu, sedangkan teori terpaan gaya hidup menekankan pada perbedaan kelas sosial.

Menurut Cohen dan Felson, perubahan struktural dalam pola aktifitas rutin mempengaruhi tingkat kejahatan melalui pemusatan tiga unsur hubungan langsung kejahatan jalanan, yaitu adanya calon pelaku yang mempunyai motif melakukan kejahatan, adanya sasaran yang cocok, dan ketidakcukupan pengawasan terhadap pelanggaran, pada waktu dan tempat tertentu. Perubahan struktural, yang lebih dipahami sebagai perubahan sosial yang terwujud dengan adanya kemajuan teknologi, merupakan faktor yang mempengaruhi aktifitas rutin, yang pada akhirnya meningkatkan resiko viktimisasi kriminal. Contohnya pencuri lebih tertarik terhadap barang atau benda yang bernilai tinggi tapi mudah dibawa dan mudah dijual. Dengan kemajuan teknologi, maka barang-barang kebutuhan manusiamenjadi semakin kecil bentuknya, namun dengan nilai guna intrinsic yang tinggi, seperti ponsel merupakan sasaran pencurian yang lebih bernilai dibandingkan pesawat telpon tetap dirumah (Mustofa, 2010 : 55-58).

\section{Metode Penelitian}

Agar tergambarkan dengan baik terkait permasalahan dalam tulisan ini bisa dilakukan dengan menggunakan metode visual kriminologi. Karena masalah ini banyak memerlukan pengumpulan bahan bukti menggunakan perangkat / data secara visual. Maka dari itu metode visual sangat cocok untuk menganalisa sebuah kasus kejahatan yang berhubungan dengan kejahatan dunia maya (cyber crime). Pada dasarnya metode visual merupakan metode

penelitian dengan menggunakan perangkat visual seperti dengan mengumpulkan gambar (foto) sebagai bukti data otentik yang ditemukan dilapangan. Metode visual telah terlebih dahulu dikembangkan dalam 
study antropology visual dan sosiologi visual. Cecil Greek (2005 ; 3) dalam tulisannya Visual Criminology : using Photography (and videography) as an Ethnographic Reseach Metod in Criminal Justice Setting menjelaskan : visual kriminologi merupakan aspek penting dalam kajian kriminologi, terutama dalam menggambarkan aspek realitas dan menangkap makna dari fenomena sosial melalui fotografi dan videografi.

\section{Analisa Permasalahan}

Munculnya

fenomena

kejahatan baru di dunia maya atau disebut juga dengan cyber crime yang mana korban kejahatan ini lebih di dominasi oleh anak dan kaum perempuan. Sebagai contoh kasus yang paling sering terjadi yaitu pelecehan seksual di dunia maya, pornografi online, perdagangan manusia, kekerasan gender berbasis online, penipuan online, cyber stalking, cyber bullying, dan lain sebagainya.

Berdasarkan data yang telah dirangkum dari beberapa penjelasan isi berita yang dimuat dalam kolom media online di atas sudah cukup jelas sekali permasalahan yang sering dihadapi dan di alami oleh perempuan ketika tersandung kasus kejahatan yang berhubungan dengan dunia maya (cyber crime) yaitu sulitnya menjangkau / mendeteksi para korban. Karena korban tidak berani untuk menceritakan kasus kekerasan yang mereka alami ke ruang publik. Contohnya korban kekerasan berbasis gender online. Mereka tidak berani melapor dan cenderung lebih menutup mulut rapat-rapat, korban takut jika di salahkan kembali oleh para penegak hukum atas kasus kejahatan yang mereka alami.

Di susul adanya perlakuan yang tidak senonoh dari pelaku, dengan mudah memperdaya dan menipu korbannya, melakukan ancaman, bahkan sampai tahap menakut-nakuti secara terus menerus. Belum lagi mendapatkan hujatan dan cemo'ohan dari para netizen pengguna sosial media di dunia maya dan masyarakat umum. Hal ini memberikan dampak buruk dan dapat menimbulkan gangguan fisik, mental serta psikologis bagi keberlangsungan hidup korban. Sehingga hal ini 
berpotensi munculnya viktimisasi pada kaum hawa.

Sebagaimana yang telah dijelaskan dalam perspektif teori viktimisasi kriminal, dalam konteks kajahatan cyber crime yang berpotensi munculya viktimisasi terhadap perempuan. Tentunya ada hubungan antara pelaku dan korban. Hal ini dikemukakan oleh Meier dan Miethe (1993) menekankan pentingnya faktor kedekatan fisik korban (calon korban) dengan orang yang termotivasi untuk melakukan kejahatan, paparan dengan lingkungan resiko tinggi viktimisasi kriminal, daya tarik sasaran kejahatan, dan ketiadaan pengawasan. Baik aktifitas rutin maupun gaya hidup sangat berperan dalam meningkatkan struktur kesempatan pelaku kejahatan karena adanya peningkatan kontak antara pelaku dengan korbannya. Nilai subyektif dari korban atau sasaran kejahatan dan tingkat pengawasan merupakan pilihan kejahatan tertentu. Kedekatan fisik dan paparan merupakan kondisi struktural, sedangkan daya tarik dan pengawasan merupakan faktor pilihan (Mustofa, 2010 : 59).

\section{Kesimpulan}

Di Indonesia, aturan mengenai cyber crime saat ini menginduk pada UU ITE. Namun, sayangnya pola penindakannya masih belum maksimal dan seringkali terkesan dipaksakan. Penegakan hukum di ranah dunia maya memang masih abu-abu karena dokumen elektronik sendiri belum bisa dijadikan sebagai barang bukti oleh KUHP.

Saat ini aktivitas cyber crime memang meningkat pesat karena tingginya angka pengguna internet maupun media sosial. Bisa di lihat hampir setiap individu masyarakat memiliki perangkat canggih berupa ponsel pribadi dan android yang selalu digunakan dalam keseharian untuk alat berkomunikasi dan melakukan transaksi jual beli hingga dipergunakan untuk kepentingan bisnis dan lain sebagainya. Hal ini seharusnya mampu membuat kita lebih waspada sehingga kejahatan yang tejadi di dunia maya ini tidak menimpa diri kita, keluarga terdekat, teman ataupun kolega bisnis.

Cara paling elegan agar tindakan cyber crime tidak semakin merajalela adalah dengan mendorong 
pemerintah membuat peraturan dan Undang-undang yang dapat menjerat para pelaku. Terutama sekali tentang tahap pendampingan, pemulihan sampai pada pemberian hak-hak para korban khususnya perempuan yang mengalami viktimisasi yang di akibatkan oleh pelaku kejahatan dunia maya (cyber crime). Selanjutnya, perlu tindakan tegas dari penegak hukum agar membuat para pelaku cyber crime berpikir panjang sebelum melakukan tindakan kriminal karena dasar hukumnya jelas.

Sebagai contoh, saat ini telah ada Divisi Cyber Crime Mabes Polri. Dengan adanya lembaga khusus seperti itu maka para penegak hukum dalam hal ini kepolisian akan mudah menangkal dan menyelidiki potensi terjadinya tindak kejahatan di ranah digital. Beberapa negara tercatat sudah mulai menerapkan konsep ini dengan membentuk lembaga khusus yang menangani persoalan cyber crime. Sehingga tidak ada celah bagi pelaku cyber crime dimanapun mereka berada. 


\section{Daftar Pustaka}

\section{Buku :}

Dimyati dan Mudjiono, (1999). Belajar dan Pembelajaran. PT. Rineka Cipta, Jakarta.

Greek, D. C. (2005). Visual Criminology: Using Photography as an Ethnographic Research Method in Criminal Justice Settings. School of Criminology and Criminal Justice Florida State University, 2-10.

Mustofa, Muhammad, 2010, Kriminologi Edisi Kedua Kajian Sosiologi Terhadap Kriminalitas, Perilaku Menyimpang dan Pelanggaran Hukum, Penerbit Sari Ilmu Pratama (SIP), Bekasi.

Rusman dkk, (2012), Pembelajaran Berbasis Teknologi Informasi dan Komunikasi. Grafindo Persada, Jakarta.

Sihite, Romani, (2007). Perempuan, Kesetaraan, Dan Keadilan : Suatu Tinjauan Berwawasan Gender, Penerbit PT Raja Grafindo Persada, Jakarta.

Udin Saefudin Sa'ud, (2008). Inovasi Pendidikan, AlfaBeta, Bandung.

Wahid, Abdul \& Muhammad Irfan, (2011),

Perlindungan
Terhadap Korban Kekerasan Seksual : Advokasi Atas Hak Asasi Perempuan, PT.Refika Aditama, Bandung.

\section{Jurnal :}

Prasetyo Hoedi \& Wahyudi Sutopo, (2018), Industri 4.0: Telaah Klasifikasi Aspek Dan Arah Perkembangan Riset, Undip, Jurnal Teknik Industri, Vol. 13, No. 1.

\section{Website :}

- $\quad$ https://qwords.com/ blog/pengertian-cyber-crime.

- $\quad$ https://www.cnnindonesia.com/ teknologi/maraknya-kekerasanterhadap-perempuan-di-duniamaya.

https://www.jawapos.com/toda y/02/01/2021/Jumlah

Perempuan Korban Kekerasan Dunia Maya di Palembang Meningkat.

https://www.bbc.com//indonesi a/trensosial.

https://www.voaindonesia.com/ kekerasan-perempuan-didunia-maya-setiap-tahunmeningkat. 